\title{
NOTE
}

\section{Induction of Ovulation by Luteinizing Hormone-Releasing Hormone (LH-RH) and Its Analogues in Rats under Various Preovulating Sexual Conditions}

\author{
Iwao YAMAZAKI, Hidekazu NAKAGAWA and KeIJi YOSHIDA \\ Medicinal Research Laboratories, Central Research Division, \\ Takeda Chemical Industries, Ltd., Osaka 532, Japan
}

\begin{abstract}
Synopsis
The ovulation-inducing effects of synthetic LH-RH and its analogues were studied in 1) proestrous rats treated with chlorpromazine, 2) persistent estrous rats produced by neonatal treatment with androgen, 3) intact rats at the diestrous stage, and 4) pseudopregnant rats produced by treatment with estrogen, and the gonadotrophic responses of ovaries and follicles in these animals were examined. The results obtained were as followes: 1) Histological examination revealed that the ovaries of the animals in the respective groups before treatment with LH-RH contained comparable populations of small- and large-sized follicles, but the population of largesized follicles tended to decrease in the following order: persistent estrous, proestrous, diestrous, and pseudopregnant rats. 2) Both subcutaneous and intravenous injections of human chorionic gonadotrophin into the animals of the respective groups induced ovulation effectively. However, the ovulating responses in terms of the threshold dose differed among the respective groups two-fold in the subcutaneous route and three- to seven-fold in the intravenous route. 3) LH-RH and its analogues administered subcutaneously or intravenously in the animals of the respective groups induced dose-dependent ovulation. Proestrous rats were the most sensitive and pseudopregnant rats were the least sensitive to the subcutaneous or intravenous injection of LH-RH. When the sensitivity of pseudopregnant rats to LH-RH was taken as 1 in terms of the reciprocal of the subcutaneous $E_{50} \mathrm{~s}$, the relative sensitivities of proestrous, persistent estrous, and diestrous animals were 950, 500, and 110, respectively. Among the analogues examined, des-Gly ${ }^{10}-\left[\mathrm{D}-\mathrm{Leu}^{6}\right]-\mathrm{LH}-\mathrm{RH}-\mathrm{ethyl-}$ amide was the most effective and also much more effective than LH-RH. The relative sensitivities to this analogue in proestrous, persistent estrous, and diestrous rats to pseudopregnant rats through the subcutaneous route were 12.8, 5.4, and 4.3, respectively.
\end{abstract}

Synthetic luteinizing hormone-releasing hormone (LH-RH), when adminisiered to a variety of experimental animals, is known to produce an effective induction of ovulation (Arimula et al., 1971; Dormody et al., 1973; Imamichi et al., 1973; Okamoto et al., 1973; Yamazaki and Nakayama, 1973). However, the results of clinical trial of LH-RH for the treatment of the patients with anovulation were unsatis-

Received February 28, 1978. factory (Zárate et al., 1973; Arai et al., 1974). The discrepancy in ovulating effect of LH-RH between experimental animals and human is due at least partly to an easy ovulation inducing condition in the former but to a difficult ovulation inducing condition in the patient with various interferences in the ovulating mechanism.

Intact diestrous rats (Eto and Imamichi, 1955 ; Imamichi and Eto, 1961), proestrous. rats in which spontaneous ovulation was. blocked by administration of chlorpromazine 
(Yamazaki and Nakayama, 1972), rats made persistent estrus after maturation by treatment with androgen during the neonatal life (Pfeiffer, 1936; Bradbury, 1941; Huffman, 1941 ; Barraclough, 1961a and b; Labsetwar, 1971; Ying, 1973), and rats made pseudopregnant by treatment with estrogen (Marckel and Nelson, 1940; Gilmore and McDonald, 1969 ; Yamazaki and Nakayama, 1971) are well-studied in the field of reproductive physiology regarding the ovulating response of the ovary to endogenous and exogenous gonadotrophin and the hypothalamo-pituitary function. The ovulating response of diestrous and proestrous rats to LH-RH has been described (Yamazaki and Nakayama, 1973; Rippel et al., 1973b; Yamazaki et al., 1977). In the present experiment, the ovulation-inducing effects of synthetic LH-RH and its analogues with relatively high activity (Fujino et al., 1972a, b and 1974) were comparatively studied by administering subcutaneously or intravenously in the four groups of animals with mutually different preovulating sexual conditions. As preliminary experiments, human chorionic gonadotrophin (HCG) was injected subcutaneously or intravenously to these animals to test the ovulation-induction as well as to compare their ovulating sensitivity.

\section{Materials and Methods}

\section{Animals}

Female Sprague-Dawley rats after purchase from Japan CLEA were maintained on a commercial diet of CE-2 (Japan CLEA) and drinking water ad libitum at an air-conditioned environment $\left(24 \pm 1^{\circ} \mathrm{C}, 50-60 \%\right.$ humidity) under illuminating $14 \mathrm{hr} /$ day from $7: 30$ to $21: 30$. The animals at ages ranging 120 to 150 days and of body weights ranging 250 to $330 \mathrm{~g}$ were examined of their vaginal smears every morning and those exhibiting regularly the sexual cycle of 4 days repeatedly more than twice were chosen for the classification into the following three groups: 1) intact diestrous rats which showed the diestrous stage at the time of LH-RH treatment, 2) proestrous rats in which the spontaneous ovulation was blocked by subcutaneous injection of $0.1 \mathrm{mg} / 100 \mathrm{~g}$ body weight of chlorpromazine (CPZ) at $15: 30$ on the proestrous day, 3) pseudopregnant rats which were persistently diestrous confirmed by the examination of vaginal smears every morning for 3 days usually on the 6th day after the subcutaneous injection of $20 \mu \mathrm{g} / 100 \mathrm{~g}$ body weight of estrone in sesame oil successively for 2 days from the estrous day (Yamazaki and Nakayama, 1971). The 4th group was classified as follows: persistent estrous rats, which were bred in this laboratory, at the age of 5 days, injected subcutaneously with $1.25 \mathrm{mg} /$ animal of testosterone propionate in sesame oil following the method of Barraclough (1961a and b). The animals showing the cornification of vaginal smears continuously for mcre than 20 days after they were above 90 days old were used.

\section{Compounds used}

Synthetic LH-RH and its analogues (Fujino et al., 1972a, b and 1974) used were LH-RH, des-Gly ${ }^{10}$-LHRH-methylamide (I), des-Gly ${ }^{10}$-LH-RH-ethylamide (II), des-Gly ${ }^{10}$-LH-RH-n-propylamide (III), des-Gly ${ }^{10}$ LH-RH-n-butylamide (IV) and des-Gly ${ }^{10}-\left[\mathrm{D}-\mathrm{Leu}^{6}\right]$ LH-RH-ethylamide (V), synthesized in these laboratories. Before use, these peptides were weighed immediately after dehydration at $50^{\circ} \mathrm{C}$ and under reduced pressure for $5 \mathrm{hr}$, and dissolved in physiological saline containing $0.1 \%$ bovine serum albumin (Wako), $20 \mathrm{U} / \mathrm{m} l$ Trasylol@ (Bayer), and $0.01 \mathrm{~N} \mathrm{HCl}$ to prepare the required dose in $0.1 \mathrm{ml} / 100 \mathrm{~g}$ body weight. Only LH-RH of three different synthetic lots was used and the respective subcutaneous $50 \%$ effective doses $\left(E_{50} \mathrm{~s}\right)$ of ovulation induction in intact diestrous rats were 252 (lot 1), 197 (lot 5), and 191 (lot 10$) \mathrm{ng} / 100 \mathrm{~g}$ body weight. HCG (Teikoku Zoki, $500 \mathrm{IU} /$ ampoule) was dissolved in physiological saline in volume of $0.1 \mathrm{ml} / 100 \mathrm{~g}$ body weight immediately before use. Each peptide of three to seven graded doses in groups of 5 to 20 animals was injected subcutaneously or intravenously at $14: 30$ in any of the animal groups.

\section{Examination of ovulation}

The animals were sacrificed by chloroform inhalation at $9: 00$ to $11: 00$ on the next day after peptide injection and the isolated oviducts were extended horizontally by inserting between two sheets of object glass for the microscopic observation of the ovulated ova. The presence of the ovum with attached granular cells more than one in the ampulla of the oviduct was regarded as a positive ovulation and an $E D_{50}$ of each peptide was calculated following the probit analysis deviced by Finney (1952).

Examination of the ovarian follicle and luteal body in size and number

Five animals chosen at random from the respective groups were killed at $14: 30$ and the left ovary 
isolated was fixed in $10 \%$ formalin followed by embedding in paraffin, serial sectioning at a thickness of $7 \mu \mathrm{m}$, and staining with hematoxillin-eosin. Thus, the serial sections were scanned microscopically and diameters of each follicle and luteal body exceeding $100 \mu \mathrm{m}$ in diameter were measured and their numbers were counted. A mean value between the maximal diameter of a follicle or luteal body and the longest line crossing with the maximal diameter at a right angle was taken as a mean diameter of the follicle or luteal body.

\section{Results}

Follicles and luteal bodies in ovaries

As shown in Table 1, the ovarian weight was extraordinarily small in persistent estrous rats, while diestrous rats showed the heaviest weight of the ovary. The luteal body more than $100 \mu \mathrm{m}$ in size was not found in persistent estrous rats at all, while pseudopregnant rats showed the relatively high frequency of the large luteal body more than $1,200 \mu \mathrm{m}$ in size. The proetrous and diestrous animals showed a similar distribution of the luteal body in size. Diestrous and pseudopregnant rats showed a comparable distribution of ovarian follicle in size but the follicle more than $900 \mu \mathrm{m}$ in size was absent in these animals. On the other hand, the ovarian follicles more than $600 \mu \mathrm{m}$ in size were comparably frequent in proestrous and persistent estrous animals. In. addition, the follicles more than $600 \mu \mathrm{m}$ in size were more frequent in the latter animals than in the former.

\section{Ovulating responses of rats to $H C G$}

HCG in either subcutaneous or intravenous route induced ovulation in each group of the animals. However, the ovulating responses were different in terms of the threshold dose and $\mathrm{ED}_{50}$ depending on the ovarian condition at the time of $\mathrm{HCG}$ injection, as shown in Table 2. The subcutaneous $\mathrm{ED}_{50} \mathrm{~s}$ of $\mathrm{HCG}$ estimated in proestrous, persistent estrous, diestrous, and pseudopregnant rats were $3.7,5.1,4.6$, and $6.9 \mathrm{IU} / 100 \mathrm{~g}$ body weight, respectively. Similarily, the intravenous $\mathrm{ED}_{50} \mathrm{~S}$ in the respective animals were $0.14,0.1-0.5,0.26$, and $0.94 \mathrm{IU} / 100 \mathrm{~g}$ body weight. Thus, pseudopregnant rats were proved to be the

Table 1. Ovarian weight and the number of follicles and corpora lutea at the time of the LH-RH administration in chlorpromazine (CPZ)blocked proestrous, androgen-produced persistent estrous, intact diestrous, and estrogen-produced pseudopregnant rats

\begin{tabular}{|c|c|c|c|c|}
\hline & $\begin{array}{l}\text { CPZ-blocked } \\
\text { proestrous } \\
\text { rats }\end{array}$ & $\begin{array}{l}\text { Androgen-produced } \\
\text { persistent estrous } \\
\text { rats }\end{array}$ & Diestrous rats & $\begin{array}{l}\text { Estrogen-produced } \\
\text { pseudopregnant } \\
\text { rats }\end{array}$ \\
\hline & \multicolumn{4}{|c|}{ Ovarian weight (mean $\mathrm{mg} \pm$ S.E.) } \\
\hline & $37.1 \pm 2.6$ & $27.2 \pm 2.7$ & $46.2 \pm 2.9$ & $36.8 \pm 2.4$ \\
\hline Mean diameter $(\mu \mathrm{m})$ & \multicolumn{4}{|c|}{ Number of follicles and corpora lutea (mean \pm S.E.) } \\
\hline \multicolumn{5}{|l|}{ Follicles } \\
\hline $100-300$ & $3.4 \pm 1.0$ & $0 \cdot 8 \pm 0.4$ & $3.6 \pm 1.0$ & $3.8 \pm 0.5$ \\
\hline $301-600$ & $12.4 \pm 1.1$ & $10.8 \pm 1.3$ & $17.2 \pm 2.3$ & $17.2 \pm 1.8$ \\
\hline $601-900$ & $6.8 \pm 1.7$ & $11.2 \pm 1.4$ & $3.8 \pm 0.9$ & $2.6 \pm 0.4$ \\
\hline $901-1,200$ & $0.4 \pm 0.2$ & $1.2 \pm 0.8$ & 0 & 0 \\
\hline$>1,200$ & 0 & 0.2 & 0 & 0 \\
\hline \multicolumn{5}{|l|}{ Corpora lutea } \\
\hline $100-300$ & 0.2 & 0 & 0 & 0 \\
\hline $301-600$ & $1.6 \pm 5.2$ & 0 & $3.6 \pm 1.0$ & $0.4 \pm 0.2$ \\
\hline $601-900$ & $4.8 \pm 0.6$ & 0 & $6.0 \pm 0.9$ & $2.6 \pm 0.4$ \\
\hline $901-1,200$ & $3.6 \pm 0.7$ & 0 & $4.6 \pm 1.4$ & $2.8 \pm 1.2$ \\
\hline $1,201-1,500$ & 0 & 0 & 0 & $4.0 \pm 0.5$ \\
\hline
\end{tabular}

Left ovaries were dissected out from five rats in each group at $14: 30$. 
Table 2. Ovulating effect of human chorionic gonadotrophin (HCG) in chlorpromazine (CPZ)-blocked proestrous, androgen-produced persistent estrous, intact diestrous, and estrogen-produced pseudopregnant rats

\begin{tabular}{|c|c|c|c|c|}
\hline \multirow[b]{2}{*}{$\begin{array}{l}\text { Dose of } \mathrm{HCG} \\
(\mathrm{IU} / 100 \mathrm{~g} \mathrm{b.w.)}\end{array}$} & \multicolumn{4}{|c|}{ No. of rats ovulating/No. of rats examined } \\
\hline & $\begin{array}{l}\text { CPZ-blocked } \\
\text { proestrous } \\
\text { rats }\end{array}$ & $\begin{array}{l}\text { Androgen-produced } \\
\text { persistent estrous } \\
\text { rats }\end{array}$ & Diestrous rats & $\begin{array}{l}\text { Estrogen-produced } \\
\text { pseudopregnant } \\
\text { rats }\end{array}$ \\
\hline \multicolumn{5}{|l|}{ Subcutaneous route } \\
\hline 2 & & $0 / 8$ & $0 / 5$ & \\
\hline 3 & $3 / 10$ & & & \\
\hline 4 & $5 / 10$ & $1 / 8$ & $0 / 10$ & \\
\hline 4.5 & & & $5 / 10$ & \\
\hline 5 & $5 / 5$ & & $9 / 10$ & $n / 5$ \\
\hline 6 & & $6 / 8$ & $10 / 10$ & $1 / 1 n$ \\
\hline 7 & & & & $4 / 10$ \\
\hline 8 & & & & $10 / 10$ \\
\hline $\mathrm{ED}_{50}$ (IU/100 g b.w.) & 3.7 & 5.1 & 4.6 & 6.9 \\
\hline (95\% fiducial limits) & $(2.6-5.0)$ & $(3.7-12.1)$ & $(4.3-4.8)$ & $(6.4-7.5)$ \\
\hline \multicolumn{5}{|l|}{ Intravenous route } \\
\hline 0.1 & $1 / 10$ & $0 / 4$ & $0 / 5$ & \\
\hline 0.2 & $9 / 10$ & & $1 / 10$ & \\
\hline 0.3 & $10 / 10$ & & $8 / 10$ & \\
\hline 0.5 & & $4 / 4$ & $5 / 5$ & $0 / 5$ \\
\hline 1 & & $4 / 4$ & & $3 / 5$ \\
\hline 2 & & & & $5 / 5$ \\
\hline $\mathrm{ED}_{50}$ (IU/100 g b.w.) & 0.14 & $0.1-0.5$ & 0.26 & 0.94 \\
\hline (95\% fiducial limits) & $(0.11-0.18)$ & & $(0.21-0.33)$ & $(0.52-1.68)$ \\
\hline
\end{tabular}

Human chorionic gonadotrophin was administered at $14: 30$.

Table 3. Ovulating effect of synthetic LH-RH and its analogues administered subcutaneously in the chlorpromazine (CPZ)-blocked proestrous, androgen-produced persistent estrous, intact diestrous, and estrogenproduced pseudopregnant rats

\begin{tabular}{|c|c|c|c|c|}
\hline \multirow[b]{2}{*}{ Compounds } & \multicolumn{4}{|c|}{$\mathrm{ED}_{50}(95 \%$ fiducial limits $), \mathrm{ng} / 100 \mathrm{~g}$ b.w., ${ }^{*}$ Relative activity to LH-RH } \\
\hline & $\begin{array}{l}\text { CPZ-blocked } \\
\text { proestrous } \\
\text { rats }\end{array}$ & $\begin{array}{l}\text { Androgen-produced } \\
\text { persistent estrous } \\
\text { rats }\end{array}$ & Diestrous rats & $\begin{array}{c}\text { Estrogen-produced } \\
\text { pseudopregnant } \\
\text { rats }\end{array}$ \\
\hline \multirow{3}{*}{$\begin{array}{l}\text { LH-KH } \\
(\operatorname{lot} 5)\end{array}$} & $24.5\left(35^{* *}\right)$ & $53.8\left(21^{* *}\right)$ & $197\left(55^{* *}\right)$ & $22,928\left(40^{* *}\right)$ \\
\hline & $(16.2-29.8)$ & $(38.9-61.0)$ & $(153-245)$ & $(15,433-63,871)$ \\
\hline & $100 *$ & $100 *$ & $100 *$ & $100 *$ \\
\hline \multirow{2}{*}{$\begin{array}{l}\text { Analogue I } \\
(\operatorname{lot} 1)\end{array}$} & $32.7\left(55^{* *}\right)$ & $73.2\left(24^{* *}\right)$ & $266(40 * *)$ & \\
\hline & $\begin{array}{c}(24.3-52.8) \\
69.1^{*}\end{array}$ & $\begin{array}{c}(51.3-130.1) \\
69.1^{*}\end{array}$ & $\begin{array}{c}(195-1,333) \\
77.8^{*}\end{array}$ & \\
\hline \multirow{3}{*}{$\begin{array}{l}\text { Analogue II } \\
\text { (lot 7) }\end{array}$} & $6.8\left(40^{* *}\right)$ & $8.2\left(21^{* *}\right)$ & $25.9\left(40^{* *}\right)$ & $225\left(30^{* *}\right)$ \\
\hline & $(6.0-7.8)$ & $(4.6-14.2)$ & $(22.5-29.4)$ & $(157-301)$ \\
\hline & $370^{*}$ & $659 *$ & $778^{*}$ & $9,860^{*}$ \\
\hline \multirow{3}{*}{$\begin{array}{l}\text { Analogue III } \\
\text { (lot 1) }\end{array}$} & $16.8\left(40^{* *}\right)$ & $22.3\left(24^{* *}\right)$ & $56.0\left(70^{* *}\right)$ & \\
\hline & $(14.0-19.9)$ & $(12.0-43.1)$ & $(47.8-64.4)$ & \\
\hline & $149 *$ & $206^{*}$ & $357^{*}$ & \\
\hline $\begin{array}{l}\text { Analogue IV } \\
\text { (lot 1) }\end{array}$ & $\begin{array}{c}1,014\left(45^{* *}\right) \\
(800-1,227) \\
24^{*}\end{array}$ & & $\begin{array}{c}6,060\left(25^{* *}\right) \\
(1,771-12,, 80)\end{array}$ & \\
\hline $\begin{array}{l}\text { Analogue V } \\
\text { (lot } 3)\end{array}$ & $\begin{array}{c}2.4^{*} \\
1.2\left(54^{* *}\right) \\
(1.0-1.4) \\
2,084^{*}\end{array}$ & $\begin{array}{c}2.8\left(24^{* *}\right) \\
(1.9-5.3) \\
1,783^{*}\end{array}$ & $\begin{array}{c}3.1^{*} \\
3.5\left(30^{* *}\right) \\
(3.0-4.3) \\
5,425^{*}\end{array}$ & $\begin{array}{c}15.3\left(30^{* *}\right) \\
(11.5-19.1) \\
149,609^{*}\end{array}$ \\
\hline
\end{tabular}

Test compounds were administered subcutaneously at 14:30. Figures in parentheses with two asterisks represent the number of rats used for calculating the $\mathrm{ED}_{50}$. 
least sensitive to the ovulation-inducing effect of HCG.

Comparison of LH-RH and its analogues in ovulating effect

In addition to LH-RH, its analogues induced ovulation in proestrous, persistent estrous, diestrous, and pseudopregnant rats in a dose-dependent manner. The subcutaneous $\mathrm{ED}_{50} \mathrm{~S}$ of $\mathrm{LH}-\mathrm{RH}$ shown in Table 3 demonstrated that proestrous rats were the most sensitive and pseudopregnant rats were the least sensitive to LH-RH. The sensitivities of persistent estrous and diestrous rats to LH-RH were rather close to that of proestrous rats. Analogue IV in proestrous and diestrous rats was markedly less effective than LH-RH. Analogue I in proestrous, persistent estrous, and diestrous animals was considerably and uniformly less effertive than LH-RH. On the other hand, analogues II, III, and V were more effective than LH-RH in proestrous, persistent estrous, and diestrous rats. Markedly strong ovulation-inducing effects of analogues II and V were demonstrated even in pseudopregnant rats, which were less sensitive to LH-RH. In addition, the intensification of the ovulating effects of these analogues was mutually different and also markedly different ac- cording to the sexual state of the animals. The intensified ovulating effect of analogues II and $\mathrm{V}$ was more marked in persistent estrous and diestrous rats and extraordinarily more marked in pseudopregnant rats than in proestrous rats, which were the most sensitive to LH-RH. On the other hand, the differences in the intensification of the ovulating effect of analogue III in proestrous and persistent estrous rats were relatively small.

Table 4 shows the intravenous $\mathrm{ED}_{50} \mathrm{~s}$ of LH-RH, analogues II, and V inducing ovulation in proestrous, diestrous, and pseudopregnant rats. The effects caused by these peptides were does-dependent and the two LH-RH analogues were markedly more effective than the mother peptide. Thus, the intravenous $\mathrm{ED}_{50} \mathrm{~s}$ of $\mathrm{LH}-\mathrm{RH}$ in persistent estrous, diestrous, and pseudopregnant rats were somewhat higher than the subcutaneous $\mathrm{ED}_{50} \mathrm{~s}$. On the other hand, the intravenous $\mathrm{ED}_{50} \mathrm{~S}$ of these analogues in all these 4 groups of rats were lower than the subcutaneous $\mathrm{ED}_{50} \mathrm{~s}$. Thus, proestrous rats and then persistent estrous rats were always the most sensitive to the ovulation-inducing effects of LH-RH and its analogues in both intravenous and subcutaneous routes. On the other hand,

Table 4. Ovulating effect of synthetic LH-RH and its analogues administered intravenously in the chlorpromazine (CPZ)-blocked proestrous, androgen-produced persistent estrous, intact diestrous, and estrogenproduced pseudopregnant rats

\begin{tabular}{lcccc}
\hline \hline Compounds & \multicolumn{3}{c}{ ED $_{50}(95 \%$ fiducial limits), $\mathrm{ng} / 100 \mathrm{~g}$ b.w. } \\
\cline { 2 - 5 } & $\begin{array}{c}\text { CPZ-blocked } \\
\text { proestrous } \\
\text { rats }\end{array}$ & $\begin{array}{c}\text { Androgen-produced } \\
\text { persistent estrous } \\
\text { rats }\end{array}$ & Diestrous rats & $\begin{array}{c}\text { Estrogen-produced } \\
\text { pseudopregnant } \\
\text { rats }\end{array}$ \\
\hline LH-RH & $21.8\left(76^{* *}\right)$ & $76.0\left(16^{* *}\right)$ & $413.4\left(75^{* *}\right)$ & $23,880\left(30^{* *}\right)$ \\
Analogue II & $(14.7-29.7)$ & $(46.1-125)$ & $(291-555)$ & $(17,012-51,649)$ \\
(lot 7) & $($ lot 1) & $($ lot 10) & $($ lot 5) & $($ lot 10$)$ \\
Analogue V & $\left(3.5\left(30^{* *}\right)\right.$ & $5.2\left(24^{* *}\right)$ & $14.1\left(30^{* *}\right)$ & $117\left(87^{* *}\right)$ \\
(lot 3) & $0.8\left(25^{* *}\right)$ & $(4.6-5.8)$ & $(11.1-17.1)$ & $(46.8-301)$ \\
\end{tabular}

Test compounds were administered intravenously at 14:30. Figures in parentheses with two asterisks rcpresent the numbers of rats used for calculating the $\mathrm{ED}_{50}$. 
pseudopregnant rats were always the least sensitive.

\section{Discussion}

The effects of LH-RH and its analogues were dose-dependent in inducing ovulation. The ovulating respose to $\mathrm{HCG}$, administered subcutaneously or intravenously, in these animals was also dose-dependent and the sensitivity was the highest in proestrous rats and then in persistent estrous and the diestrous rats and the least in pseudopregnant rats. However, the differences in the $\mathrm{ED}_{50} \mathrm{~s}$ of $\mathrm{HCG}$ in these animals were relatively small. On the other hand, the large differences in $\mathrm{ED}_{50} \mathrm{~s}$ of $\mathrm{LH}-\mathrm{RH}$ between proestrous rats on one hand and persistent estrous, diestrous, and pseudopregnant rats on the other were demonstrated. Thus, such a characteristic difference in the ovulation-inducing effect of $\mathrm{LH}-\mathrm{RH}$ according to the sexual state may mainly be due to the difference in the sensitivity of the pituitary to release gonadotrophin.

Modification of the pituitary sensitivity to endogenous or exogenous LH-RH by the level of circulating steroid hormones was demonstrated (Debeljuk et al., 1972a and b; Arimura and Schally, 1970). In androgen-produced persistent estrous rats, the ovaries showed a significant decrease in weight, absence of the large luteal body indicative of the decreased progestational activity, and relative increase in large follicles indicative of the dominant release of estrogen and androgen into the circulating blood (Weisz and Lloyd, 1965). And these steroids have been shown to decrease the release of $\mathrm{LH}$ from the pituitary in response to exogenous LH-RH (Debeljuk et al., 1972a). In estrogen-produced pseudopregnant rats, the increased presence of large luteal bodies associated with the decreased presence of large follicles probably indicates that the relatively increased progestins depress the sensitivity of the pituitary to the exogenous LH-RH. In fact, the release of $\mathrm{LH}$ from the pituitary in response to exogenous LH-RH was reported to be depressed by progesterone alone or in combination with estrogen (Arimura and Schally; 1970). LH-releasing responsiveness of pituitary to LH-RH differing considerably according to the sexual cycle was shown to be the highest in proestrous rats and the lowest in diestrous rats (Rippel et al., 1973a; Gordon and Reichlin, 1974). This finding agrees well with the present evidence that CPZ-blocked proestrous rats are the most sensitive to LH-RH and its analogues in inducing ovulation.

The ovulation-inducing effects of analogues II and V were more marked than those of LH-RH not only in proestrous rats but also in persistent estrous, diestrous, and pseudopregnant rats. The intensification of the ovulating effects of these analogues was mutually and markedly different according to the sexual state of the animals. In addition, the intravenous $\mathrm{ED}_{50} \mathrm{~s}$ of these analogues were always smaller than the subcutaneous $\mathrm{ED}_{50} \mathrm{~s}$. The rate of absorption from the site of injection into the circulating blood, the rate of disappearance from the blood, and the binding ability to the pituitary tissue of LH-RH and its analogues may be mutually different.

\section{Acknowledgements}

The authors are grateful to Dr. Ryo Nakayama for his kind guidance and helpful advice throughout this study. They are grateful to Dr. Kiro Shimamoto for his kind guidance and help in preparing the manuscript. They also wish to express their gratitude to Dr. Masahiko Fujino for supplying the synthetic LH-RH and its analogues. 


\section{References}

Arai, K., T. Yanaihara, and S. Okinaga (1974). Sanfujinka Chiryo 29, 1. (In Japanese)

Arimura A., H. Matsuo, Y. Baba and A. V. Schally (1971). Science 174, 511.

Arimura, A. and A. V. Schally (1970). Endocrinology 87, 653.

Barraclough, C. A. (1961a). ibid. 68, 62.

Barraclough, C. A. (1961b). ibid. 68, 68.

Bradbury, J. T. (1941). ibid. 28, 101.

Debeljuk, L., A. Arimura and A. V. Schally (1972a). ibid. 90, 1578.

Debeljuk, L., A. Arimura and A. V. Schally (1972b). Proc. Soc. Exp. Biol. Med. 139, 774.

Dermody, W. C., R. R. Humphrey and J. R. Reel Hypothalamic Hypophysiotrophic Hormones: Physiological and Clinical Studies (edited by C. Gual and E. Rosemberg). Excerpta Medica, Amsterdam, p. 56 (1973).

Eto, T. and T. Imamichi (1955). Endocrinol. Japon. $2,149$.

Finney, D. I. Probit Analysis. Cambridge Univ. Press, Cambridge, (1952).

Fujino, M., T. Fukuda, S. Shinagawa, S. Kobayashi, I. Yamazaki, R. Nakayama, J. H. Seely, W. F. White and R. H. Rippel (1974). Biochem. Biophys. Res. Commun. 60, 406.

Fujino, M., S. Kobayashi, M. Obayashi, T. Fukuda, S. Shinagawa, I. Yamazaki, R. Nakayama, W. F. White and R. H. Rippel (1972a). ibid. 49, 698.

Fujino, M., S. Kobayashi, M. Obayashi, S. Shinagawa, T. Fukuda, C. Kitada, R. Nakayama, I. Yamazaki, W. F. White and R. H. Rippel (1972b). ibid. 49, 863 .
Gilmore, D. P. and G. P. McDonald (1969). Endocrinology 85, 946.

Gordon, J. H. and S. Reichlin (1974). ibid. 94, 974. Huffman, J. W. (1941). ibid. 29, 77.

Imamichi, T. and T. Eto (1961). Jap. J. Animal Reprod. 7, 103 (In Japanese).

Imamichi, T., T. Miura and T. Saito (1973). 75th Meeting of Veterinary Soc. Jap. Abstr. p. 2 (In Japanese).

Labsetwar, R. P. (1971). Acta Endocrinol. 66, 266.

Marckel, C. and W. O. Nelson (1940). Anat. Rec. 76, 391 .

Okamoto, M., H. Nakano and T. Nobunaga (1973). 75 th Meeting of Veterinary Soc. Jap. Abstr. p. 2 (In Japanese).

Pfeiffer, C. A. (1936). Am. J. Anat. 58, 195.

Rippel, R. H., E. S. Johnson and W. F. White (1973a). Proc. Soc. Exp. Biol. Med. 143, 55.

Rippel, R. H., E. S. Johnson, W. F. White, M. Fujino, I. Yamazaki and R. Nakayama (1973b). Endocrinology 93, 1449.

Weisz, J. and C. W. Lloyd (1965). Ibid. 77, 735.

Yamazaki, I. and R. Nakayama (1971). J. Takeda Res. Lab. 30, 49.

Yamazaki, I. and R. Nakayama (1972). Endocrinol. Japon. 19, 175.

Yamazaki, I. and R. Nakayama (1973). Folia Endocr. Japon. 49, 189. (In Japanese).

Yamazaki, I., H. Nakagawa, K. Yoshida and R. Nakayama (1977). Jap. J. Fert. Steril. 22, 46. (In Japanese).

Ying, S.-Y. (1973). Proc. Soc. Exp. Biol. Med. 144, 822.

Zárate, A., E. S. Canales, A. V. Schally, A. J. Kastin and J. Soria Hypothalamic Hypophysiotrophic Hormones: Physiological and Clinical Studies (edited by C. Gual and E. Rosemberg). Excerpta Medica, Amsterdam, p. 251 (1973). 